\title{
DEPRECIATION AND EFFECTIVE RATE CONTROL
}

\author{
JOHN BAUER $\dagger$
}

IN the June issue of the Yale Law Journal ${ }^{1}$ I proposed outright estab. lishmient of prudent investment as the rate base for future regulation of public utilities, as now permitted by the decision of the Supreme Court of the United States in the Hope Natural Gas Company case. ${ }^{2}$

The establishment of a prudent investment rate base would require initial determination of (1) the original construction cost of all the plant and equipment used in furnishing public service, and (2) the past depreciation of the properties due to all causes, both physical and functional. The accounts of each company would be rewritten accordingly. The initially adopted rate base would consist of the original cost as entered in the plant accounts, less the depreciation as shown by the adjusted depreciation reserve, plus definite accounting provisions for working capital. Subsequently, further accruing depreciation would be charged regularly to operating expenses and would be added or credited to the reserve; new construction would be entered in the plant accounts at actual cost; and the original cost of items retired (less salvage) would be deducted both from the plant accounts and from the reserve.

With such continuous accounting the balance of all the plant accounts would present at any time the original cost of the properties in service, and the reserve would show their total accrued depreciation. The balance, plus working capital, would be the prudent investment or the rate base, on which the company's allowable return would be predicated. Shown directly by the accounts, the rate base would not be subject to future revaluations. It would involve no time-consuming and costly procedure for determination, as in past rate cases. It would conserve equally and definitely the rights of investors and consumers. Rate control would become a matter of systematic administration, instead of intermittent and spasmodic brawls of litigation.

f Director, The American Public Utilities Bureau.

- This article was prepared in collaboration with Mr. James M. Carroll, former City Solicitor, Springfield, Massachusetts. We discussed extensively the basic ideas in connection with recent Springfield utility cases; he aided in planning the article, made important suggestions in the preparation of the manuscript, and, in particular, passed on the legal issues and views that are presented.

1. Bauer, The Establishment and Administration of a "Prudent Intvestment" Rate Base (1944) 53 YaLB L. J. 495.

2. Federal Power Comm. v. Hope Natural Gas Co., 320 U. S. 591 (1944). 
In thus presenting the prudent investment rate base, the carlier article gave general consideration to the two depreciation problems, initial determinations ${ }^{3}$ and subsequent accruals. ${ }^{4}$ This article will consider more specifically the chief aspects of depreciation discussing, first, the nature of depreciation and how it is properly ascertained and provided for, second, past commission treatment of depreciation in accounting regulation and in rate and capitalization cases, and third, the scope of existing depreciation and the importance of making proper and definite pruvisions for effective public control. Finally, a reply will be made to the criticisms of the prudent investment rate base contained in Mr. Samuel Ferguson's article in the September issue of the Journal. ${ }^{5}$

\section{What Depreciation Is and How It Is Properly Ascertamed}

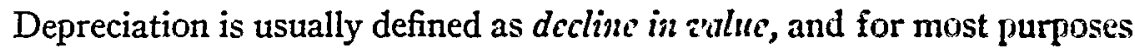
this simple view is adequate. It signifies measurement of decrease cumplared with a particular value at a prior time or with the cost of acquisition. It may pertain to a business as a whole, to a special part of the business, to individual property items, or to an aggregate of plant units.

The term connotes (1) developing depreciation as time goes on (i.e., rate of depreciation for a period of time), and (2) the amount of total accumulated or accrued depreciation at any moment. However, the decline in value concept as properly applied to ordinary business is objectionable in its application to public utilities unless it is clearly understood that regulation has to do with costs and not with alues in the ordinary commercial sense. This is particularly true where prudent investment, duly maintained, constitutes the rate base. Although this is definitely a cost category, and not one of value as that word is commonly used, the long years of "fair value" discussion witnessed incessant economic and legal disputes over what was really involved, costs or values. Fortunately, this source of confusion has at last been removed, and commissions are now permitted, so far as the Supreme Court is concerned, to proceed with regulation throughout on a cost rather than a value basis.

Cost Allocation. From this cost standpoint, the depreciation concept as embodied in modern regulatory utility accounting involves cost allocation from plant or capital account to operating expenses, with corresponding total accrual in the depreciation reserve.

During the economic usefulness of the individual plant units, or class of units, their original cost is written off and charged to operating expenses

3. Bauer, supra note 1 , at 508-10.

4. Id. at 510-11.

5. Ferguson, "Cost" as a Substitute for "I"alue" in Utility Rote Base Detcrmingtion: A Comment on Dr. Baner's Position (1944) 53 YALE L. J. 721. 
in accordance with their decline in total effective serviceability. At any given time the depreciation of existing plant items consists of the amount of their original cost that has been written off to past operating expenses. The balance, or the depreciated cost, is applicable to future operation and constitutes the prudent investment. In this manner plant and operating accounts, if properly maintained, will furnish standards for regular and effective public control.

This cost view of depreciation can be harmonized with value decline as commonly referred to in public utility parlance. If cost is clearly kept in mind, utility depreciation can be satisfactorily expressed as decline in service value. When plant units are installed new, their cost is then recognized as constituting their full service value and is entered accordingly in the accounts; each item embodies the sum of its total future serviceability as reflected by its cost. As time passes, the sum of economic serviceability gradually decreases with operation, and the cost is correspondingly charged, or allocated, to operating expenses. Thus "decline in service value" can be taken as defining depreciation for the purposes of public utility regulation."

6. The following definition, taken from FEDERAL Power Commission, UNIform System of Accounts for Public Utmities and Licensees (1937) 5, presents the view of depreciation that has come to be widely accepted for regulatory purposes:

"'Depreciation', as applied to depreciable electric plant, means the loss in service value not restored by current maintenance, incurred in connection with the consumption or prospective retirement of electric plant in the course of service from causes which are known to be in current operation and against which the utility is not protected by insurance. Among the causes to be given consideration are wear and tear, decay, action of the elements, inadequacy, obsolescence, changes in the art, changes in demand and requirements of public authorities."

This definition is applied by the FPC to the original cost of the properties used in public service and represents the same general perspective outlined in this article. The definitions and discussions in the accounting textbooks usually lack precision and are applicable to ordinary private business not subject to regulation of rates and other phases of public interest. The clearest and most appropriate accountant's definition presents depreciation as "expired capital outlay." This is definitely a cost concept, developed by P. D. Leake, in DePRECLATION AND WASTING ASSETS (1912). According to Leake's view, the purchase of a plant unit to be used in operation for longer than one regular accounting period is charged to capital or plant account at cost, which then "expires" as operation proceeds, and is correspondingly charged to operating expenses and accumulated in the depreciation reserve. This concept and procedure agree with the cost perspective that is essential to effective regulation.

Apart from clarity of concepts, accountants accept the general cost view for plant accounts and for depreciation provisions. However, they tend to regard as fundamental the "principle" that the plant charges must reflect solely cost to the purchaser regardless of the original installation cost. While this view pertains properly to ordinary industrial acquisitions, it should be modified in its application to public utilities, since these concerns are subject to an underiying .public interest whose conservation is the primary function of regulation. The accounting standards, therefore, should conform with the regulatory purposes. Because of the public interest, the total cost to the purchaser is subject to classification to 
It should be emphasized, however, that this service value concept is definitely a cost and not a value category. Value, as generally applied to unregulater industrial properties, depends upon future net earnings above operating costs and reflects such prices or rates charged for the products as can be obtained under expected market conditions, without the regulatory restrictions to which public utility rates and earnings are subject. ${ }^{7}$ In contrast, service value is a cost quantum which must be established before rates can be administratively fixed, and which serves as the basic element in their determination. As here presented, it signifies depreciated or net costs, ${ }^{3}$ not just original or gross costs. In its totality for any company it is equal to the original cost of the properties kept in service, less their full depreciation determined in relation to their original cost, plus working capital. ${ }^{3}$

Causes of Depreciation. The basic fact in declining service value as thus defined is the diminishing balance of total serviceability, as time and uperation proceed, due to physical and functional depreciation, as revealed by the comparison of the existing plant units with available new ones.

From a purely physical point of view, existing units wear out or otherwise deteriorate and must finally be retired. Such physical decline in service value can be either measured or reasonably estimated. When the original cost is correspondingly allocated to operating expenses and is gradually replaced by an equal amount of assets kept bads in the business by depreciation accounting, the full original investment is regularly conserved.

Depreciation due to functional causes is less simple to perceive and more difficult to determine. It reflects the changing relation of the existing plant units and their net cost to available superior units and their cost. The existing units depreciate as improved or otherwise more suitable new ones become

show the original cost of plant in service and to present separately the pay ment in excess of original cost. The principle here is that the underlying public right is fixed when plant investments are first made and is not prejudicially affected by subsequent sales and purchases. For severe criticism on "principle," see Paton, Accounting Policies of the Fedcrol Power Commission (1944) $77 \mathrm{~J}$. Accountancy 432; in reply, see Bater, Accombing Prisciples of the Federal Power Commission (1944) 78 id. at 28S. See also Bauer, The Fussetions

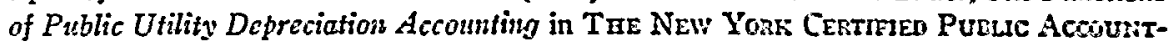
ANT, October, 1944.

7. The term zalue can be properly applied to a utility pronerty only as the result after the rates have been fixed and the earnings realized accordingly, as then established in the consequent market prices of the company's outstanding securities. Such ziduc can be greater or less than the "service value" or rate base depending upon the earnings as expacted and upon the investment market. With effective regulation, the r'alse of a property normally could not depart greatly from the underlying service value or rate base.

S. "Rate base," "depreciated cost," "net cost," and "service value" will be used interchangeably in this article as embodying the same cost factors.

9. The working capital element of the rate base will be ignured in the rest of the discussion, but it will be assumed to be subject to regular accounting determination along with the plant costs and depreciation. 
available; the relative superiority of the available determines the depreciation of the actual. Replacement or substitution takes place when the superiority of the available overbalances the entire cost of the existing. By this time the full original cost has been recovered, provided the plant investment has been systematically maintained by means of depreciation accounting.

In most utility properties, and especially in the case of electric companies, physical depreciation is normally blanketed by the functional. The latter has two general causes: scientific and technological progress in available plant units and shifts in service requirements. Functional decline due to progressive improvements in available units is termed obsolescence. As plant improvements become available, either in manufactured units or in methods of construction, existing units depreciate and are ultimately superseded when the balance of over-all economy requires acquisition and operation of the new. The relation is expressed in the following general equation of relative costs:

Interest or return on the depreciated cost of actual plant units + their greater operating expenses and maintenance $=$ interest or return on the full cost of available new units + their lower operating expenses and maintenance.

Both sides of the equation are calculable in relation to full or regular plant - operation. When the balancing of over-all cost per unit of product or service results in zero service value for the old, it is replaced by the new, except as items may economically be kept in reserve at zero to meet peak service demands and special operating contingencies. ${ }^{10}$

Functional depreciation caused by shifts in service requirements may result from increasing or decreasing demands upon existing plant or from changes imposed by public authority. Increasing service demands produce so-called inadequacy. As service requirements advance, existing units gradually reach the point of complete inadequacy and have to be replaced by larger units, or supplemented. If inadequacy is met by direct replacement, the original cost gradually expires up to the point of replacement. If, however, inadequacy is met, not by direct displacement, but by supplementary installation, the measurement of accruing depreciation involves all the related facilities. Their total depreciation at any time is equal to an amount which leaves their combined net plant cost equal to the full cost of a comprehensive new layout of required service capacity, taking into account the differences in relative operating expenses. ${ }^{11}$

10. Such extra capacity may be supplied either by old units at zero net cost or by new units at full cost.

11. This phase of inadequacy is widely prevalent, but it is less apparent and its determination is more complicated than simple replacement. It is therefore usually obscurcd and largely ignored although it commonly exists. Its ascertainment again involves comparison of actual with available plant units. 
While service requirements normally increase, they sometimes diminish. When this is true, existing plant units depreciate as their original cost exceeds the cost of new units adequate for the lower service needs. This phase of functional depreciation has never received a specific name, but in contrast to inadequacy it represents ozcr-adequacy of existing units compared with appropriate new ones.

Shifts in service conditions appear also with reference to plant location, especially as required by public authorities. For example, street changes may necessitate the relocation or placement underground of electric lines. While such prospective shifts may be less subject to prevision than the development of inadequacy or over-adequacy, they nerertheless affect the remaining serviceability of the existing property units. Where the changes may reasonably be anticipated, they are properly included in the depreciation accounting, provided that the cost of relocation is payable by the contpany and thus by the consumers. ${ }^{12}$

Relation of the Actual to the Arailable. The concept that functional depreciation of the actual units in service is due to the progressive availability of superior new ones has not received general recognition. It is seldum avowed even by those who insist upon full operating provision for functional as well as physical changes. While they recognize that original cost must be conveyed to operation during the period of economical operation, so that the full amount will be recovered in retainerl assets by the time of retirement, they seldom see clearly that the declining service value throughout the period depends upon an over-all cost comparison of the old units with the progressively available new.

Sometimes functional decline is correlated with loss uf efficiency or other suitability within the existing plant units themselves. This view, of course, is untenable. If, for example, obsolescence were caused by loss of operating efficiency by the units in service, without comparison with superior available units, there would be little obsolescence. Most plant items maintain substantially their original efficiency for operation up to the time of retirement and are scrapped or rendered useless only because they are too inefficient compared with up-to-date new units. What causes functional depre-

12. The question sometimes arises whether the regular deprecintion charges in ulu also include provisions for plant contingencies and casualties. In general, as to operating function, it should not. Depreciation consists only of decreases in service value that develop in the course of operation. Destruction of properties by storms, fluods, fires, ctc., is properly covered by insurance or by some special accounting pruvision (by the creation of a separate contingency reserve, or by first charging extraordinary losses to an asset suspense account and then amortizing them over a reasonable period of years). While all such losses should be absorbed as cost in the operating expenses and piad for by consumers, they do not constitute depreciation. However, regular provisions for them can be included in the charges to operating expenses, so that the reserve will cuver not only the accrued depreciation but also accumulations fur plant casualties. Xlinur losses are best charged directly to operating expenses along with ordinary maintcnamse. 
ciation is not internal loss of serviceability but external progress, with existing plant units depreciating as better ones become available. The term "economic" serviceability has been used to designate the equated usefulness of the actual units in relation to the superior new ones that are available. Physical serviceability, on the other hand, could be obtained without dite regard to relative efficiency and suitability for economical operation. ${ }^{13}$

While comparative serviceability furnishes a clear view of accruing depreciation, the rate or amount can seldom be calculated with fine accuracy and must therefore be subject to adjustment with passing time. Estimates have to be made in advance for considerable periods, including, at the outset, the total expected life of newly installed plant units. Consequently, precise correspondence between the accounting and the underlying forces of functional decline cannot be maintained. If, however, long-distance judgments are subject to constant revision in the light of technological and service developments, intelligent management and regulation can keep the accounting provisions substantially in harmony with the actual depreciation.

The Straight Line Method. For the purpose of making regular provisions for depreciation accounting, the so-called straight line method has received extensive approval by competent analysts and regulatory bodies. It involves, first, an initial estimate of the total economic service life of the plant units as installed, and, second, the allocation of their original cost (less expected salvage) to operating expenses in equal periodic amounts.

The method is simple and can be accepted as furnishing an accounting standard which is practical and reasonable throughout. Its characteristics, however, should be understood, and it should be subject to continuous managerial and regulatory scrutiny for needed adjustments. If the original life expectations should prove wrong, an appropriate change in the time basis should be made. Furthermore, while the formula sometimes has received doctrinal credence as if it furnished per se the basic measure of depreciation, actually it does not in itself provide for regular economic cost equalization of old units with available new ones. Such comparison would generally reveal relatively greater depreciation during the earlier years of the total economic.life, producing, instead of a straight line, a descending one. This would correspond with the usual operating fact that newly installed plant units are devoted as steadily as possible to the main service loads while older

13. A special phase of functional depreciation that is usually overlooked appears when new sub-units are installed in connection with a general plant layout that has incurred extensive obsolescence. While such new units may be economically justified and properly entered in the plant accounts at their full installation cost, actually they are then functionally as depreciated as the corresponding or associated old units. They are as obsolete as is the plant as a whole. Their immediate depreciation should not bc obscured. The over-all provisions for the plant as a whole should be adequate to cover the total depreciation incurred in regard to all the units installed at the various stages of the entire plant's developing obsolescence. 
ones are relegated to successively less important functions until they are finally retired from service. For most kinds of plant units a schedule of diminishing annual depreciation would correspond better to the underlying facts than the straight line method of equal annual allocations to operating expenses.

To attempt such precise adjustments of annual depreciation for the different classes of plant would doubtless involve an amount of technical and accounting detail that would not be justified as a regular operating matter. Moreover, total plant usually consists of an aggregate of various short-and long-lived units, and of old, new and in-between items, as a result of gradual additions, improvements and replacements that extend back over many years. Under such conditions, the straight line method can be accepted as a satisfactory average means of providing regularly for depreciation if it is used intelligently and not blindly as a formula. ${ }^{14}$

Reserves and Actual Depreciation. Practical treatment of depreciation, of which the straight line method is an example, raises the question whether accounting provisions can ever, or normally, be accepted as the true measure of depreciation. At best, of course, determination of the actual involves estimates as to which there can be substantial differences of opinion between persons with like general views, purposes, ability and integrity.

If, however, clear perspective guides the initial and subsequent findings, adjustments in accounting can reasonably approximate the actual depreciation. Furthermore, under definite regulatory standards and procedure, the showing of the accounts, once officially established, would furnish the sole measure of the actual depreciation with validity for rate-making and other regulatory and financial purposes. The charges and reserve as once approved would stand as final at that time, and all needed adjustments would be reflected in the subsequent charges to operating expenses and in the corresponding reserve accruals.

This assumes definite standards and systematic accounting provisions for reguluatory purposes. Unfortunately, no such standards have existed in the past or prevail now, but they should be adopted for the future. If they are, the first step is to obtain proper initial accounting adjustments in the showing of original plant costs and accrued depreciation; subsequently, regular depreciation provisions will be made according to sound managerial judgment under commission control. If this is done, the total depreciation

14. Adjustment in annual depreciation charges and reserve aceruals would be predicated primarily upon different functional development than had been previously espeeted. In the case of obsolescence, for example, it would usually be due to faster or slower technological advancement. It might be due also to shifts in price levels or construction costs, so that the period of economic serviceability would be extended or shortened by the prospect of a higher or lower level of plant costs with which operating comparisons would be made. 
accounted for will always be reasonably close to underlying actualities and can be taken as an exact amount in dealing with relative public and private rights. The objective is definiteness, with reasonable assurance of sound financial policy, equal justice to consumers and investors, and regulation predicated upon recognized showing of facts rather than upon the morass of opinion and conjectures which was typical of the old type of rate case procedure.

Relation to Reproduction Cost. Inasmuch as the depreciation of the actual plant units is correlated with the cost of available new ones, it may be asked whether the result is not equivalent to appraisal at reproduction cost new less depreciation. Since outright reproduction cost less depreciation has been the determining part of the past "fair value" standard, why this legal and accounting strain to substitute prudent investment?

The answer appears chiefly in the definiteness and administrability thereby attained. While, theoretically, original cost less depreciation as here presented has similarity to reproduction cost less depreciation correspondingly computed (if the relative quantities are comparably determined throughout), the adoption of prudent investment would simplify the determination of the rate base and would eliminate conflicts of interest. Both original cost and depreciation, when once initially ascertained and embodied in the accounts, could subsequently be shown as definite amounts through regular accounting procedure. Except for possible extravagant or otherwise unwarranted plant charges, which would be disallowed immediately by the commission, there would be exactness and life permanence in the plant costs as currently incurred and entered in the accounts. Accruing depreciation would be predicated upon managerial and regulatory judgment; but it would be computed according to established standards and procedure involving no conflict of interest between consumers and investors. Neither side would gain any advantage by an excessive or inadequate periodical allowance, and neither could rationally oppose proper provisions for depreciation as it occurred. At any time the rate base would be shown by the accounts as an exact sum.

In contrast, when reproduction cost less depreciation is used, both factors that enter into the net amount are not only difficult to ascertain but must be redetermined with each rate inquiry. Because of opinion testimony and lack of exact showing of facts, every step leading to rate base findings involves basic conflicts, with the result that rate cases are cumbersome, costly, time-consuming, and not manageable for regular and systematic administration. Under the consequent procedure, the private side is usually fully prepared and expertly presented, while the public side goes extensively by clefault. Finally, when the rate base has been deterfnined after protracted proceedings in virtual litigation, the reproduction cost as found is almost inevitably excessive and the depreciation inadequate, thus differing mate- 
rially or greatly in result from original cost less depreciation as shuwn by accounts under continuous regulatory scrutiny.

My objection to the discarded "fair value" rule and my lung support of prudent investment, with a definite accounting rate base, have never been based upon conceived basic advantages for consumers as against investors. Except for its lack of definiteness and determinability, I have not been opposed to reproduction cost less depreciation as such. Furthermore, unless one ignores shifts in price levels and movements of cost, he can not escape giving effect indirectly to the reproduction cost element. The prudent investment rate base doutbless involves, indirectly at least, an aspect of reproduction cost, but it keeps to exactness of factual showing, precludes conflicts of basic interests, protects equally and definitely the relative rights of consumers and investors, and provides for regular and systematic administration. Its administrability on the basis of factual definiteness is its compelling claim to adoption for regulatory purposes.

\section{Compission Action on Deprectation}

Recent renunciations by the Supreme Court, especially in the Hope Natural Gas Company case, ${ }^{15}$ have left regulatory bodies virtually supreme in fixing rates without specific judicial restrictions affecting bases or methods. ${ }^{16}$ Even with respect to the remaining requirement that over-all results represent a fair balance between investors and consumers. ${ }^{17}$ the burden rests heavily upon the utilities to prove conclusively that there has been injustice. ${ }^{18}$

This new freedom does not relieve the commissions, however, from their own responsibility for doing their work systematically, in continuous fairness to both public and private interests, by planning and establishing improved standards and procedures through which rate-making can be made a matter of regular and definite administration predicated upon exact facts as shown by the records and accounts.

15. Federal Power Comm. v. Hope Natural Gas Co., 320 U. S. 591 (1944).

16. 'Under the statutory standard of "just and reasumable' it is the result reached not the method employed which is controlling. . . . It is not theory but the impast of the rate order which counts. If the total effect of the rate order cannot be said to be unjust and unreasonable, judicial inquiry under the [Natural Gas] Act is at an end. The fact that the method employed to reach that result may contain infirmities is not then important." Id. at 602 .

17. "The rate-making process under the Act, i.e., the fixing of 'just and reasonable" rates, involves a balancing of the investor and the consumer interests." Id. at 603 .

18. ". . . the Commission's order does not become suspect by reason of the fact that it is challenged. It is the product of expert judgment which carries a presumption of validity. And he who would unset the rate order under the Act carries the heavy burden of making a convincing showing that it is invalid because it is unjust and unreasonable in its consequences." Id. at 602. 
As an important factor both in the rate base and in operating expenses, depreciation received its share of judicial attention during the long controversies over "fair value." ${ }^{19}$ Now, within the limits of general fairness, the commissions are left free to use independent discretion in making provisions for depreciation in the total rate-making process. If this responsibility is to be effectively discharged, traditional attitudes, standards and procedure

19. Depreciation was not mentioned in the original pronouncement of the United States Supreme Court on "fair value" in Smyth v. Ames, 169 U. S. 466 (1898), first appearing as a separate factor in Knoxville v. Knoxville Water Co., 212 U. S. 1 (1908). There, and in the Minnesota Rate Cases, 230 U. S. 352 (1913), the Court gave evidence of recognizing both physical and functional depreciation. See especially 230 U. S. at 456, 458. The statement in McCardle v. Indianapolis Water Co. (1926), however, that the "testimony of competent valuation engineers who examined the property and made estimates in respect of its condition is to be preferred to mere calculations based on averages and assumed probabilities" (272 U. S. 400, 416) was widely interpreted as stipport for depreciation deductions based exclusively upon physical inspection. In the same case the Court further remarked, in rejecting a city estimate of the cost of a substitute steam plant, that what was to be ascertained was "the value of the plant used to give the service and not the estimated cost of a different plant" (id. at 417-8), a distinction which has since been hurled against any consideration of available plant units in the determination of the "fair value" of existing properties.

The Knoxville case made clear that past inadequate provisions in the charges to operating expenses and in the accumulation of reserve would not prevent the full deduction of depreciation. However, the reverse situation of excessive depreciation charges and reserve accumulations was not presented until Board of Pub. Util. Comm'rs v. N. Y. Telephone Co., 271 U. S. 23 (1926), where the offsetting of high past charges by a reduction of current provisions for depreciation was not permitted. Following this telephone case the position of the Court was generally accepted to be (1) that currently accruing depreciation must be included in operating expenses, and (2) that total actual depreciation is deductible from cost new in the determination of "fair value." Depreciation charges were customarily based upon original cost, even though the rate base rested primarily upon reproduction cost. United Rys. \& Elect. Co. of Baltimore v. West, 280 U. S. 234 (1930), held, however, that depreciation allowances in operating expenses must also be predicated upon reproduction cost.

Release of the commissions from unworkable restrictions has come since 1930. Lindheimer v. Illinois Bell Telephone Co., 292 U. S. 151 (1934), recognized that the depreciation provisions for operating expenses must be in harmony with the total deducted for rate base determination, defining depreciation as "the loss . . . due to all the factors causing the ultimate retirement of the property ... [including] wear and tear, decay, inadequacy, and obsolescence." Id. at 167. In Los Angeles Gas \& Elect. Co. v. R. R. Comm., 289 U. S. 287 (1933), the use of the actual cost of the properties rather than reproduction cost was approved, and in Federal Power Comm. v. Natural Gas Pipeline Co., 315 U. S. 575 (1942), the Court upheld the Commission in the fixing of rates on the basis of original cost less full depreciation and in the inclusion in operating expenses of accruing depreciation predicated on original cost. Finally, in Federal Power Comm. v. Hope Natural Gas Co., 320 U. S. 591 (1944), it approved the deduction of total depreciation due to all causes from original cost in determining the rate base and the basing of operating charges for accruing depreciation on original cost, explicitly overruling United Rys. \& Elect. Co. v. West supra. 320 U. S. at 606-7. 
will need thorough revision to meet the needs of constructive future regulation.

Past commission dealing with depreciation as a direct regulatory matter has largely reflected the general ineffectiveness of regulation in practice. The reașons have included inadequate or restrictive statutury powers, judicial restrictions and requirements, unclear perception, insufficient financial and staff provisions, and political conditions.

The commissions have dealt with depreciation in perfurmin three majur regulatory functions: (1) accounting, (2) rate-making, and (3) contrul of security issues. In none have they adopted and applied definite standarls or protected systematically the relative public and private rights. While their failure-has in jured the consumers much more directly and extensively, it has affected indirectly the investors, especially bond and preferred stuck owners, by not requiring adequate depreciation reserves and so permittin: extensive payment of common-stock dividends out of capital. Sume billions of outstanding public utility securities today have no investment suppurt and, upon definite reckoning between consumers and investors, will be left without return.

The purpose here is not to berate the commissions but rather to sxilain how their failure to deal properly with depreciation came alsuut and, cially, to emphasize what they must do if regulation is to be recunstituted as an effective instrument of public policy. The reasuns for plast mistaliss are understandable, but the necessary changes must be made if resulation is to meet its institutional requirement. Where immense public and private rights are involved, lackadaisical processes are intolerable and must be replaced by measures which are constantly directed to clear objuctives and are regularly administered on the basis of definite rights and continuwus showing of exact facts.

1. Lack of Poa'er in Accounting. The basic obstacle in accounting regulation has been inadequate legal authority and responsibility to deal comprehensively with depreciation. The commissions in ogeneral have had neither the power nor duty to fix annual depreciation rates or to require proper charges to operating expenses with corresponding accrual to depreciation reserves.

Although the companies commonly have been required to report what was actually done, they have been largely free to adopt annual depreciation rates and accounting in accordance with financial policies fixed by their boards of directors. Usually the provisions have been inadequate. While at times the commissions have applied non-legal pressures, they have generally been ignored, although in recent years, especially upon action by the Federal Power Commission and the Securities and Exchange Commissinn, the annual depreciation charges have been substantially increasted and hislier 
relative reserves have been accumulated than had been the record up to roughly the middle of the $1930 \mathrm{~s}^{20}$

The commissions should, of course, have full power and duty to require the companies to make reasonable charges to operating expenses for all causes of depreciation and to accumulate reserves accordingly. Fiurthermore, where past provisions have been inadequate, so that the reserves arc less than the actual physical and functional decline, they should have the power and duty to make fair determinations and to order a corresponding adjustment of the reserves. Unfortunately, no state commission is today clothed with adequate legal authority and responsibility for such effective accounting revision and control.

2. Rate Case Difficulties. While the commissions have not had appropriate powers in the field of regular accounting, they have had both the right and duty to make due depreciation provisions in the fixing of reasonable rates. This has applied both to the allowances for operating expenses and to rate base deductions.

In dealing with this double aspect of depreciation in rate cases, the commissions have made the basic determinations. Their grave obstacle was the method of factual ascertainment, depending not upon definite accounts and records but upon expert opinions presented in quasi-judicial inquiries. Under such procedures, as outlined above, ${ }^{21}$ the company's side was ustually prepared and presented in much more detail, and much more impressively, than the consumers'. The determinations almost inevitably favored the companies. This uneven treatment is evident in the common provisions for operating expenses in contrast to the rate base deductions. The commissions have usually made allowances in operating expenses roughly or nearly in accordance with the actually developing depreciation, with annual rates ranging between 2 and 3 per cent on the cost new of the properties. But after making such provisions in the rate paid by consumers, they have not had the power to compel inclusion of equivalent charges in the companies' accounts. Consequently, while total accruing depreciation was provided for

20. According to the Federal Power Commission's Statistics of Eltectric Utilities IN THE UNITED STATES : 1942, the ratio of total "reserves for depreciation and amortization of utility plant" to "total utility plant" was $15.5 \%$ as of December 31,1942 , for all class A and class $B$ privately owned electric companies reporting to the Commission. The corresponding ratio was $11.6 \%$ as of December 31,1938 . Id. at viii.

The controlling reason for inadequate past depreciation provisions was, presumably, a financial one: to keep the showing of operating expenses as low as possible; and that of net earnings as high as possible, so as to pay the dividends for the support of the overcapitalized holding company structures. This was the prevalent situation with the electric systems. However, with the telephone companies, and especially the natural gas companies, the situation was normally the reverse: excessive depreciation charges were usually made so as to cover up high net earnings and so head off demands for rate reductions.

21. Supra, p. 100. 
in gross revenues, the companies continued to show lower annual custs and higher net earnings than realized and to pay dividends accordingly on the widely prevalent overcapitalization, passing them to the higher reaches of holding company structures.

The immediate incongruity appears between the allowances for operating expenses and the rate base deductions. As against the annual provisions of 2 to 3 per cent on the cost new of the properties, the total depreciation deductions have commonly ranged between 10 and 15 per cent, seldum as high as 20 per cent. These total percentages are obviously inconsistent with the allowed annual depreciation rates. An annual rate of 2 per cent, in relation to total depreciation of 10 or 15 per cent, involves an average plant agse of only 5 or 7.5 years, or only 10 years for a 20 per cent total. 13 per cent annual rate is equivalent to an average age of 3.4 years, 5 years, ur 6.7 years, to correspond with 10,15 or 20 per cent total depreciation. Inasmuch as the properties covered in the ordinary rate proceeding were develuped uver a long period of years, with gradual additions and replacements extending back at least 30 years and often over 50 , the assumption of an average age of only 5 to 10 years is absurd. 22 If the annual depreciation rate of 2 to 3 per cent is correct and is duly correlated with the ages of the variuus classes of property, the total depreciation must be 30 per cent or wer, the extent depending upon the accumulation of old plant items that have little or nu actual service value.

In presenting their planned and detailed expert testimuny; the cumpanies have commonly and calmly ignored the inconsistency between the claimed annual and the total depreciation. The consumer representatives have frequently insisted, relying usually on general logic and analysis, that either the annual depreciation provisions were grossly excessive or the total depreciation provisions were correspondingly inadequate. However, upun the records of evidence presented, and upon previews of possible court action, the commissions have followed the company position and claims more nearly than logic and the underlying realities. They have certainly failed, on the whole, to harmonize their findings on annual charges and on tutal depreciation. $^{23}$

3. Approval of Security Issues. The control of security issues presents a third phase of commission treatment of depreciation. Where state statutes

22. While there should be correspondence between the annual charges and tutal depreciation, the annual rate multiplied by average age may not always give the currect tutal yercentage. This is due, in physical depreciation, to serial collapse ui the plant units within the estimated average service life, and, in functional depreciation, to changes in the life estimates as operation proceeds. However, though the results of multiplying annual rate and age cannot be followed as a simple formula, they furnish at least apprusimate indication wi total depreciation for the different classes of property.

23. This was especially true prior to the middle 1930 s. 
have provided for such regulation, both the language and the procedure as adopted have usually disregarded altogether the factor of depreciation, approval being predicated primarily upon the actual cost of the properties installed.

The common practice has been for a company to make plant additions and improvements on its own decision, paying for them out of corporate funds or through short-term loans, typically demand notes not subject to commission control. Then, after such plant outlays have reached a substantial total, the company has applied to the commission for approval to issue securities, equal in amount to the expenditures, for the declared purpose of reimbursing the corporate funds or repaying the temporary loans. At that point the commission has sometimes required a staff investigation of plant additions and retirements and has allowed new bonds or stock to be issued equal to the plant additions less retirements made during the period covered by the petition, usually since a previous authorization was granted.

This procedure ignores the depreciation of the properties. Irrespective of inadequacy of the reserve or of the accrual of depreciation during the period covered, the authorization is predicated exclusively upon the so-called net plant additions (the cost of the new, less the cost of the retired), and approval is normally granted even where the previously outstanding securities exceed the prudent investment in properties devoted to public service. The standard disregards prior overcapitalization and does not even take into account depreciation accruing between approvals. While it deducts retirements as made, it fails to include in that deduction fully depreciated plant units kept in pretended service to sustain high rate base valuations or to support excessive security issuances.

Apart from dealing with prior overcapitalization, the correct standard would be to approve new securities only to the extent of increase in total plant costs over further accrued depreciation during the period covered. The allowance should equal the total plant expenditures, less the plant retirements and the additional plant depreciation. Furthermore, it should not be limited to reimbursement of funds already expended but should be predicated at the outset upon an approved construction program. The public interest is affected by the very plans and acts of construction, not merely by subsequent financial standards in approving security issues. ${ }^{24}$

24. Many examples can be cited of commissions' disregard of the public interest in dealing with depreciation in rate cases, security issues, plant retirements and other phases of regulation. Three recent cases of which I have first-hand knowledge are here summarized. [In the first two MIr. James M. Carroll represented the City of Springfield as Solicitor while I was engaged as economic adviser and expert.]

The first is a rate case following a complaint filed by the Mayor of the City of Springficld, Massachusetts, against the United Electric Light Company of that city, with the Massachusetts Department of Public Utilities (hereinafter referred to as DPU) in Case No. 5943, June 16, 1941. This commission had always given lip service to the prudent investment rate 


\author{
Improvement in Standards. While past commission dealings with depre- \\ ciation in the various phases of regulation involving public and private
}

base concept but had never taken a clear position on the regulatiun of the originally prudent plant expenditures to their subsequent depreciation. In this case the City contended that the company's steam generating plant was completely depreciated because of its age and consequent inefficiency, compared with an available new plant. The old plant regularly required about two pounds of coal per kilowatt hour generated while less than one pound is needed by a new modern plant. But, since the plant was still "used and useful" as a standby, DPU allowed the original cost as included in the plant accounts to romain in the base upun which rates were fixed. While the original construction was doubtless prudent, the entire cost should have been charged off to past operating expenses and covered fully in the depreciztion reserve. The records showed, moreover, that past rates paid by cunsumers had heen more than adequate to provide fully for aceruing depreciation and tu pay a return of more than 6 per cent on prudent investment. The DPU adoptcd as the rate base the original cost of the plant minus only the company-reported reserve predicated on inadequate past charges to operating expenses for depreciation. The next year (1942), in a Federal Power (",mmissinn hearing on the consolidation of the United Electric Light Cimpany with wher oparating companies, the Chief Engineer of United admitted the steam plant was unceonumical and not in regular use except as a relay center and that necescary puwer was therefure purehsesd from the Hartford Electric Light Company of Hartford direetly or through assuciatel companies.

The second case, Petition of Springheld Strcet Ry., Mass. DPC, Case Xu. 6355 (1943), involved a series of orders of the DPU relating to the cumplete al andunment in 1940 , i a street railway system and the substitution therefor of motor huses. I'ractically $n$, previsiun had been made for past depreciation. Consequently, the clean climinatin $n$ ir m the halanse sheet of the road-and-equipment item representing trolley uperation wuld have revealed a large corporate deficit. The stock had been approved when issued and then doultler; represented prudent investment. But the plant back of the stuck was mut maintaind and was gradually depreciated and abandoned through the years, with the maju.r changkent $\mathrm{cr}$ t. buses, taking place in 1940. This rèsulted in the entire property back uf the to tal to sh in tue bsing dissipated. Nevertheless, the DPU, over the abjection of the (ity of Springfieh and nearhy communities, authorized the transfer of the bulk of the dead asuts th an asset suspense account and then approved the amortization of these accuunts threugh clarges t.1. . pisting expenses as current depreciation. The DPU thus saved the company from shoving tits a twal deficit, ignored basic standards of preserving prudent investment, and authorized an accusuting set-up which will naturally be used by the company to sustain excessive lius fares.

The third case was before the Connecticut Public Utilities Commission and inrulved the New Haven Water Company. In re New Haven Water Co., Docket Xiv. 7075, June 21, 1943, 49 P.U.R. (N.S.) 229, 236-40. The issue was the functional depreciation of the iurms chief water supplies which were stated at a total book cost of $\$ 3,395,000$, and had a sate daily production capacity of about 23 million gallons. When this supply had besume inadejuate, a new source was developed at a cost of $\$ 7,128,000$. This furnished a safe daily additiun of 15 million gallons; but with the extension that had been part of the comprehensive plan an addition of 24 million gallons a day could be obtained at a further outlay of abuut $\$ 2,000,000$, which would eliminate the need for the old supplies. My position was that the depreciation of the old supplies was properiy determined in relation to the cost of the available substitute, and involved primarily an equated relative cost of determination. Id. at 239 . While there were pluses and minuses for other minor factors whose amounts could not be established with desirable exactness (as is commonly true in rate cases), they were evidently not controlling in the decision. The deciding view was that I had shifted from the prudent invest- 
interests have been unsatisfactory, the prospects for improvement appear encouraging. First, the commissions have already applied pressure for more adequate depreciation charges to operating expenses. Second, they are tending more to require congruity in rate case findings between operating expense allowances and total depreciation. Third, they are moving toward harmonization of regular accounting with rate base needs and toward the development and application of standards that depend upon definite factual showing rather than upon opinion testimony and quasijudicial procedure. Fourth, they have been released from the previous shackling by judicial requirements and restrictions.

The progress made in general position and attitude is striking in the accounting field. During recent years the National Association of Railroad and Public Utility Commissioners has had a special committee on depreciation accounting, which in 1943 issued a comprehensive document known as the NARUC depreciation report. ${ }^{25}$ This embodies, in the main, the standards that have been adopted and applied by the Federal Power Commission and the more advanced state commissions. It recommends the adoption of the straight line method of determining annual depreciation charges, providing for current functional decline as well as for physical wear and deterioration, and predicates the annual depreciation rates tupon the original cost and the total expected service life of the various classes of property. While some minor criticism can validly be made, the report marks a new era in commission accounting standards. ${ }^{26}$

The report also takes a quite positive stand on corrections that should be made for inadequate past provisions for depreciation. It recommends that the reserves be adjusted to the annual depreciation charges and proposes retroactive application of the current depreciation rates to the ages of the various plant items. The plant accounts of a company would show the actual

ment in the actual plant to an evaluation of a hypothetical substitute plant. Although the Commission was undoubtedly sincere, its position, I submit, involves a grave economic misapprehension. While the rate base determination must, of course, pertain to the actual plant, how can the findings of functional depreciation be intelligently reached except by comparing the efficiency and suitability of the existing plant units with superiar available ones?

25. Report of Committee on Depreciation of National Assoctation of Railkoad AND UtilitTes CoMsrissioners (1943).

26. There had been considerable foundering among commissions in providing for depreciation accounting. In the earlier classifications, the official accounting usually provided for depreciation as such, sometimes under such title as "amortization of fixed capital." However, during the 1920 s there was extensive official shift to so-called retirement accounting, providing, for both the annual charges and the reserves, amounts sufficient only to equalize plant retirements over five to ten years. This change was sanctioned by the NARUC, partly no doubt under private utility influences and partly perhaps to recognize the actual accounting practice of the companies. The recent reverse shift, returning to outright depreciation accounting, has been led particularly by the federal commissions and reflects the more recent realistic and positive consideration of the public interest by most regulatory bodies. 
original cost of the properties used in service, and the reconstructed depreciation reserve would present the part of the original cost that is properly applicable to past operation. The balance would show the remaining net plant investment.

All this is good modern accounting. The report is somewhat tender, however, in applying its retroactive recommendations to a company whose adjusted reserves would result in showing a balance sheet deficit. Such a situation would, of course, raise a question of policy: is it better to avoid outright showing of insolvency and to force corporate reorganization or to cover up the actuality and assist the company in placing the burden of reattaining solvency upon the consumers without corporate reorganization?

The answer should be plain. Where past rates have been adequate to cover all operating costs and a fair return, but inadequate depreciation charges have been made, there can be no injustice if the depreciation reserves are now rewritten upon full retroactive application of proper annual percentages. Where past rates have not been sufficient to cover all costs along with depreciation and a fair return, revision of the reserve should still be made if the fault for not getting adequate earnings was the company's because of inefficient operation or failure to apply for justified rate increases. Where industry conditions precluded a fair return ahwe all operating costs, proper charges for depreciation shuuld have been made ahead of return, and full reserve adjustment again appears justified. On the other hand, where past rates as fixed by commission urder did nut provide adequately for depreciation, and where no more than a fair return was obtained, retroactive revision of the reserve would he unjust, and the required adjustment should, of course, take into account the past rate restrictions. Such instances, however, are rare since the commissions have virtually always allowed full depreciation for operating expenses in rate eases. In the great majority of instances no substantial issue of fairness can be raised by complete reserve adjustments. ${ }^{27}$

\section{Prevalent Depreciation and Needed Adjustuent}

If a generally fair and definite rate base is to be established, the major problem is the initial determination of total existing depreciation. Once

27. Perhaps it is inept to view the present adjustments in the depreciation reserves as retroactive application of current depreciation rates. The term "retreactive" has a sinister and oppressive connotation. Actually the adjustments involve no retresctive impast in the real economic and legal sense. They merely bring the reserve aceounts up to the depreciation that has, in fact, taken place. Inasmuch as legally and procedurally actual depreciation is deductible from the cost new of the properties in the rate base determinatiuns, there is no $e x$ post facto penalty upon the companies if the reserves are adjusted to the underlying realities that must be evaluated in dealing effectively with relative public and private rights. Such demarcation becomes significant in the rate-making process. The proposed accounting adjustments would greatly facilitate the continuous showing of those relative rigits but would not alter their basic content and amount. 
these findings have been made and entered into the accounts, subsequent provisions for further accruing depreciation will involve no particular conflicts of interest and no special difficulties of ascertainment.

The rate base for each company can then be shown as an exact anount beyond the realm of dispute. However, the initial findings of depreciation will necessitate detailed inspection of the properties and thorough analysis of the operating suitability of the various units. The work can be kept within manageable confinés, but it will place substantial burdens upon the fact-finding bodies. It will require clear perception of what is involved, the adoption of workable standards and procedure, and the use of skilled personnel.

Extent of Existing Depreciation. To make clear the importance of the task a rough indication of the extent of existing depreciation may be useful. This will be limited to the electric industry, but similar conditions are prevalent in other utilities.

In considering any electric generating plant and its depreciation, a clear understanding of modern plant standards is essential. Under present conditions large central stations of high efficiency are available for virtually all distribution areas. For the most part, therefore, the over-all cost of such modern generation furnishes the measure of depreciation in the existing plants. The best example is electric generation by steam as measured by use of coal. A large modern plant (except for war conditions) can ustally bo constructed for not more than $\$ 100$ per kilowatt of installed capacity and can be operated at an average coal consumption of about $0.75 \mathrm{lb}$. per kilowatt hour. However, for 1942 the Federal Power Commission reported total bituminous coal consumption of $64,372,000$ short tons for production of $100,569,000,000$ kilowatt hours of electric energy, or a country-wide average of $1.28 \mathrm{lbs}$. per kilowatt hour. ${ }^{28}$ The same average is given for New England. If the available plant requiring $0.75 \mathrm{lb}$. of coal per kilowatt hour generated is compared with the actual steam plants in New England, the available saving is $0.53 \mathrm{lb}$. per kilowatt hour. Regular full-load operation may be assumed to average 5,300 hours a year; therefore each kilowatt of existing capacity will require $2,800 \mathrm{lbs}$., or 1.4 tons, more than modern plant. With coal at $\$ 5.00$ per ton, the average excess cost is $\$ 7.00$ per year per kilowatt of installed capacity. This is equivalent to 6 per cent on $\$ 117$, compared with $\$ 100$ of modern plant cost per kilowatt. Merely as an aver-

28. See Federnl Power Conrmission, Consunption of Fuel for Production of ELECTRIC ENERGY : 1942, Table I, pp. 2-3. This table presents, by months for 1942 and total for the year, the short tons of bituminous coal consumed for production of electric energy, total kilowatt hours generated during the year, and the pounds of coal per kilowatt hour, for the United States as a whole, for each region, and for each state within each year. 
age, therefore, the available coal saving alone would render existing New England steam plants entirely obsolete. ${ }^{20}$

The economic advantage of new plant in each region, ur for each company, would depend upon the available coal saving, the cost of coal, the interest rate on new funds, and the cost per kilowatt of new plant. Surveys would have to be made separately for each company. The determination should include available savings not only in coal consumption but also in labor and materials for operation and maintenance.

For transmission, distribution and general plant, no convenient standard of comparison between existing and available plant can be adopted for illustration. However, the forces of depreciation have been at work, and their effect should be ascertained. Surveys of transmission and distribution lines would establish their suitability compared with new ones that could be provided now; the latter might have different capacities, different location, superior materials, and would involve more efficient methods of construction. The relative over-all economy and suitability would establish the depreciation of the existing lines.

Determinations of this nature would require detailed facts and estimates and would involve differences of opinion and conflicts of interest. Simplification could be achieved, however, by holding close to established plant ages and annual depreciation rates on which agreement can often be reached. Whatever the difficulties encountered, they should be met squarely and sensibly. Definite results will have to be established within the vast reaches of existing indefinitenesses; ascertainment of depreciation is essential for initial establishment of prudent investment and is unavoidable if future regulation is to be effective.

Future Definite Provisions. Once the initial findings of existing depreciation have been officially set and the reserves adjusted accordingly, the annual depreciation rates applied to different classes of property can be readily estimated on the basis of the reasonable life expectancy indicated by physical and technological prospects and can be adjusted with recognized change in expectations. The same amounts would be entered as charges to operating expenses and as credits to the reserve, and relative equity and definite balance between consumers and investors would be maintained. When, however, excessive or inadequate provisions became apparent, revision in subsequent depreciation rates would be made. The goal would be to keep as close as practicable to the actual development of depreciation while presenting throughout exact amounts for purposes of regulation.

To carry through the depreciation program as outlined will require, first

29. This summary analysis is based generally on 14,000 b.t.u. coal. Where the b.t.u. content is materially less, the calculation vould have to be adjusted accurdingly. 
of all, adequate legislation. This should convey to the commission in each state the power and duty to establish a definite system of regulation based factually upon accounts and records. It should fix standards and prescribe procedure as far as practicable both for the initial determination and the subsequent accounting. It should provide sufficient funds and appropriate personnel.

The commissions should be lifted from their prevalent political and easy. going levels to competent, public-minded, vigorously functioning bodies which realize that they are entrusted with great powers and responsibilities for the protection and advancement of enormous public interests. There is no more important matter of postwar planning and transformation if the general system of private utilities under state regulation is to be maintained against the encroaching establishment of outright public organization and management.

\section{RePLi to Mr. FERGUSON}

'In the September issue of the Journal Mr. Samuel Ferguson, President of the Hartford Electric Light Company, presented a critical discussion of my proposals for the establishment of a "prudent investment" rate base. Mr. Ferguson's position may be briefly stated as follows:

First, that while the proposed prudent investment rate base is presented as a quantum of cost, it is in reality one of value. ${ }^{31}$ He views depreciation as a value category, with no causal or logical relation to cost. The latter he regards as a fact established once and for all through purchase or installation, not subject to diminution through the forces of depreciation. ${ }^{32} \mathrm{Sec}-$ ond, that the depreciation concept and accounting as presented constitutes in fact amortization of investment and not depreciation. ${ }^{38}$ Third, that the depreciation provisions as outlined are destructive of the underlying investors' rights. ${ }^{34}$ Fourth, that the depreciation accounting and treatment for rate-making purposes as set forth would prompt the utility managements to make uneconomical plant replacements. ${ }^{35}$

The first point has already been discussed at some length. As has been stated, ${ }^{36}$ the prudent investment concept here presented is definitely one of cost and not value in the commercial sense. The charges for depreciation to operating expenses and the credits to the reserves are in fact cost allocd-

30. Ferguson, "Cost" as a Substitute for "Value" in Utility Rate Base Determination: A Comment on Dr. Baner's Position (1944) 53 Y ALE L. J. 721.

31. See $i d$. at $721,723-4$.

32. See id. at 723-4.

33. See id. at 732 .

34. See id. at 731.

35. See id. at 721, 727-30.

36. Sitpra, pp. 93-5. 
tions, not value adjustments. The original cost of plant units is yradually absorbed by the charges to operating expenses for depreciation as the total economic serviceability of the plant units diminishes with operation and age. And, while accruing depreciation is determined in relation to available new plant units, its entry into the accounts is purely a cost allocation.

Mr. Ferguson's second point may be disposed of along with his first. The current accounting represents throughout depreciation as total plant serviceability declines and not amortiation of investment. The depreciation processes fully preserve or maintain the investment as made, providing regular replacement of the accruing depreciation through the immediate cash assets retained in the business. The investment is kept permanently unimpaired and intact. In contrast, amortization gradually extinguishes the amount of original investment over a period of time. Mr. Fergusion has confused the two opposite accounting objectives and procedures.

His third point, that the depreciation provisions are destructive of underlying investors' rights, is also a misconception. The outright purpose is to establish, maintain and protect equally the relative rights of investors and consumers. The question is whether the accounting squares with the ubjective. The answer appears indubitable. Capital cost as initially incurred is manifestly the measure of original investment. This amount, plus subsequent further investments in plant additions, is regularly maintained through the plant and depreciating accounting, and it constitutes the rate base on which a fair return would be allowed at all times through the rates paid by consumers. Manifestly there can be no impairment or confiscation of investment, directly or indirectly.

On this point, Mr. Ferguson produces an illustration intended to demonstrate inequitable reduction of return to stockholders as a result of the depreciation procedure. ${ }^{37}$ However, what he attempts to show deals with the rate of return allowable on the rate base and not with the rate base itself, the sole subject of discussion in both the June and present articles. The rate of return should, of course, be fair ; and, naturally, confiscation of investors" rights can be effected by fixing an unfair rate of return as well as by adopting an inadequate rate base.

Extensive consideration of what is a fair rate of return cannot be attempted in this abbreviated reply, but a summary disposition will be presented under Mr. Ferguson's fourth point, that the depreciation accounting would result in uneconomical plant replacements. First, he obviously misunderstands. the accounting process and, second, he again shifts from rate base to rate of return. When complete depreciation accounting has been provided, the rate base cannot be reduced or increased by retirement and replacement of depreciated plant items. Consequently, there would be no

37. See Ferguson, supra note 30 , at 727-8. 
motive for the management either to discard plant units prematurely or to continue them in operation longer than economically justified.

In contrast, however, if Mr. Ferguson's proposal of gross plant costs, without the depreciation accounting and the reserve deduction, ${ }^{38}$ were adopted as the rate base, the management would be induced to keep fully depreciated plant units beyond the time when economically they should be retired. As long as they are continued in pretended use, they would be kept in the rate base at full original cost, but, when retired, the rate base would be reduced by the amount of the original cost. Thus retirement would be postponed as long as specious justification, such as peak use, reserve, or standby, could be concocted for the continued benefit of the company and its stockholders. This unhappily has, often been the situation under past rate base standards and procedure.

Mr. Ferguson fails to face the clear rate base situation just presented. His point is predicated upon illustration, not explicit investment analysis, and it involves rate of return instead of investment. He takes the original plant costs of his own company, $\$ 40,000,000$, deducts the depreciation reserve, $\$ 10,000,000$, and so presents the prudent investment rate base at $\$ 30,000,000$. On this net investment he assumes a 6.5 per cent rate of return, or $\$ 1,950,000$ per annum. Included in the $\$ 40,000,000$ plant costs is the sum of $\$ 3,000,000$ for "an old low pressure steam plant built 40 years ago." This is considered suitable to meet reserve needs, while $\$ 4,000,000$ would have to be spent for new generating capacity if the old plant were retired. ${ }^{30}$

By this presentation of facts, Mr. Ferguson attempts to show that, with the prudent investment rate base, the company would derive an advantage from premature retirement of the old plant. Upon retirement the original cost of all the properties would be reduced from $\$ 40,000,000$ to $\$ 37,000,000$, and upon installation of the new plant the amount would be advanced to $\$ 41,000,000$. With the retirement of the old unit, the reserve would be diminished from $\$ 10,000,000$ to $\$ 7,000,000$. The net rate base after the retirement would still be $\$ 30,000,000$, as before, but with the new plant installation would be increased to $\$ 34,000,000$, on which a return of 6.5 per cent would come to $\$ 2,210,000$, or an advance of $\$ 260,000$ over the return prior to the replacement. Mr. Ferguson assumes that the $\$ 4,000,000$ for the new plant units could be borrowed at 3 per cent, and so would cost $\$ 120,000$ a year, against the gain of $\$ 260,000$ in the return obtained at 6.5 per cent on the total rate base. The retirement and replacement would thus yield an unwarranted advantage of $\$ 140,000$ to the stockholders. ${ }^{40}$.

With the facts just as stated and assumed, Mr. Ferguson is right: the management would be prompted to make premature replacements. But the

38. Id. at 730 .

39. Id. at 728-9.

40. Id. at 729 . 
trouble is not in the rate base, but in the relation of the rate of return to the assumed interest rate. Naturally, if the company is allowed a 6.5 per cent return on the prudent investment rate base while it can get capital funds at 3 per cent, it will profit from premature replacements. Mr. Ferguson is wrong, however, even in the consideration of his figures on his theory. If undepreciated original cost were adopted as the rate base, the annual return at 6.5 per cent on $\$ 40,000,000$ would be $\$ 2,600,000$, instead of $\$ 1,950,000$ on prudent investment (and here is the lure of the proposal), while after the retirement and replacement the rate base would be $\$ 41,000,000$ and the return at 6.5 per cent would be $\$ 2,665,000$. The increase in return would be only $\$ 65,000$ against the additional interest cost of $\$ 120,000$ on the borrowed funds. Under this situation, there would be uneconomically delayed instead of premature replacement.

The trouble both ways is in the relation of the 6.5 rate of return to 3 per cent for the cost of borrowed money. The two percentages are incongruous. When funds can be borrowed at 3 per cent, a 6.5 per cent over-all rate of return is unwarranted. Naturally, just as there should be no profit to the company in juggling the rate base, so there should be no advantage in trafficking between money rates. The rate of return should be adjusted to basic costs of moneys; there would then be no profit or loss in premature or delayed replacements. But this is another story. 